\title{
ANALISIS PENGARUH PELAYANAN JASA INSTALATIR LISTRIK TERHADAP KEPUASAN KONSUMEN PADA BIRO JASA CV. KELUARGA MANDIRI LAMONGAN
}

\author{
Evi Fitrotun Najiah \\ Prodi Manajemen, Fakultas Ekonomi, Universitas Islam Lamongan \\ Jl. Veteran No. 53A Lamongan \\ Telp. (0322) 324706, Faks. (0322) 324706 \\ Evifitrotun25@gmail.com
}

\begin{abstract}
ABSTRAK
Metode penelitian yang digunakan dalam penelitian ini adalah metode observasi, wawancara, kuesioner, dan studi kepustakaan dengan menggunakan skala likert, penentuan sampel yang digunakan adalah simple random sampling sebanyak 50 sampel. Metode analisis data yang digunakan adalah metode regresi linear berganda, korelasi, uji F dan uji t. Dari uji regresi linier berganda diperoleh $\mathrm{Y}=3.881+0,251 \mathrm{X} 1+0,465 \mathrm{X} 2$ Besarnya koefisien korelasi berganda $(\mathrm{R})$ sebesar 0,791 ; hal ini berarti menunjukkan adanya hubungan yang kuat antara variabel daya tanggap dan kehandalan terhadap kepuasan konsumen CV. Keluarga Mandiri Lamongan. Berdasarkan uji $F$ diketahui $F_{\text {hitung }}: 39.208$ dan $F_{\text {tabel }}: 3,20$; maka $F_{\text {hitung }}>F_{\text {tabel }}$, maka variabel daya tanggap dan kehandalan berpengaruh secara simultan terhadap kepuasan konsumen. Berdasarkan hasil uji t diketahui nilai thitung sebesar 2,435 dan $t_{\text {tabel }}$ sebesar 2,012 ( $t_{\text {hitung }}>t_{\text {tabel }}$ ) untuk variabel daya tanggap dan hasil uji t diketahui nilai t hitung sebesar 3,969 dan t tabel sebesar 2,012 ( $\left.\mathrm{t}_{\text {hitung }}>\mathrm{t}_{\text {tabel }}\right)$ untuk variabel kehandalan. Dari hasil penelitian tentang analisis pengaruh pelayanan jasa instalatir listrik terhadap kepuasan konsumen pada biro jasa CV. Keluarga Mandiri Lamongan, hasilnya adalah variabel daya tanggap dan kehandalan berpengaruh secara simultan dan parsial, dapat disimpulkan bahwa variabel kehandalan berpengaruh paling dominan terhadap kepuasan kosumen pada CV. Keluarga Mandiri Lamongan.
\end{abstract}

Kata kunci : Kepuasan Konsumen dan Pelayanan Jasa

\section{PENDAHULUAN}

Usaha pelayanan jasa instalatir listrik yang berada di Lamongan saat ini semakin berkembang pesat, hal itu terbukti dengan semakin banyaknya pelayanan jasa instalatir listrik yang beroperasi di wilayah Kabupaten Lamongan. Dengan adanya kenyataan tersebut mengiindikasikan bahwa persaingan pelayanan jasa instalatir listrik di Lamongan semakin ketat. Agar usaha tersebut dapat bertahan diantara banyaknya persaingan pelayanan jasa sejenis, maka para pelaku bisnis jasa instalatir listrik biasanya melakukan berbagai macam upaya, semisal melakukan promosi.

Selain promosi, adapun usaha yang dilakukan dalam pelayanan jasa tersebut yaitu, dengan mengutamakan 
cara kerja yang efektif dan efisien dalam menyelesaikan tugas yang telah diorder. Pelayanan jasa yang berkualitas bukan hanya mengacu pada hasil yang telah dicapai saja. Tuntutan para pelanggan untuk mendapatkan pelayanan yang lebih baik.

Kualitas pelayanan yang memberikan dorongan khusus bagi para pelanggan untuk menjalin ikatan relasi saling menguntungkan dalam jangka panjang dengan perusahaan. Ikatan emosional semacam ini memungkinkan perusahaan untuk memahami dengan teliti harapan dan kebutuhan spesifik pelanggan, dengan demikian perusahaan dapat meningkatkan kepuasan pelanggan. Adapun kualitas pelayanan dinilai dari kehandalan atau kemampuan memberikan pelayanan sesuai dengan yang dijanjikan, daya tanggap dengan memberikan pelayanan dengan cepat dan tepat, merupakan jaminan yang diberikan pihak perusahaan sehingga pelanggan bisa memberikan kepercayaan, empati atau perhatian dari kualitas yang telah diberikan serta keamanan yang bisa bebas dari suatu bahaya, risiko atau keragu-raguan.
CV. Keluarga Mandiri merupakan salah satu badan usaha penyedia jasa instalatir listrik, dalam menjalankan usahanya ada beberapa jasa yang ditawarkan yaitu : pembayaran rekening listrik bulanan, pasang baru, perubahan daya, migrasi (perubahan meteran listrik) dan proyek instalasi listrik. Di Lamongan CV. Keluarga Mandiri memiliki beberapa pesaing dalam menjalankan usahanya, agar bisa memenangkan persaingan tersebut peningkatan kualitas pelayanan kepada konsumen diutamakan karena hal ini merupakan kunci untuk memenangkan persaingan dengan badan usaha pelayanan jasa sejenis. Untuk mengetahui apakah pelayanan yang telah diberikan kepada konsumen selama ini telah sesuai dengan harapan konsumen pada CV. Keluarga Mandiri. Tujuan penelitian ini adalah Untuk mengetahui apakah variabel pelayanan jasa (daya tanggap dan kehandalan) berpengaruh secara simultan terhadap kepuasan konsumen pada CV. Keluarga Mandiri Lamongan. Untuk mengetahui apakah variabel pelayanan jasa (daya tanggap dan kehandalan) berpengaruh secara 
parsial terhadap kepuasan konsumen pada CV. Keluarga Mandiri Lamongan dan untuk mengetahui variabel mana yang berpengaruh lebih dominan terhadap kepuasan konsumen pada CV. Keluarga Mandiri Lamongan.

\section{KAJIAN PUSTAKA}

Pemasaran adalah $r$ suatu
sistem keseluruhan dari kegiatan
bisnis yang ditujukan $r$ untuk
merencanakan, menentukan harga,
mempromosikan
mendistribusikan barang dan jasa
yang memuaskan kebutuhan, baik
kepada pembeli yang ada maupun
pembeli potensial (Murti Sumarni dan
John Soeprihanto, 2014 : 265).
Sedangkan menurut Philip Kotler
(2009:5) pemasaran adalah mengidentifikasi dan memenuhi kebutuhan manusia dan sosial.

Menurut Valarie A. Zeitharal dan Marry Jo Bitner (2008) Jasa adalah suatu kegiatan ekonomi yang outputnya bukan produk dikonsumsi bersamaan dengan waktu produksi dan memberikan nilai tambah (seperti kenikmatan, hiburan, santai, sehat) bersifat tidak berwujud.

\section{METODE PENELITIAN}

Menurut Sugiyono

(2008)

metode kuantitatif sering dinamakan metode tradisional, positivistik, scientific dan metode discovery. Metode kuantitatif dinamkan metode tradisional, karena metode ini sudah cukup lama digunakan sehingga sudah menjadi tradisi sebagai metode untuk penelitian. Metode ini disebut sebagai metode positivistik karena berlandaskan pada filsafat positivisme. Metode ini sebagai metode ilmiah/scientific karena telah memenuhi kaidah - kaidah ilmiyah yaitu konkrit/empiris, obyektif, terukur, rasional dan seitematis. Metode ini juga disebut metode discovery, karena dengan metode ini dapat ditemukan dan dikembangkan berbagai iptek baru. Metode ini disebut metode kuantitatif karena data penlitian berupa angka - angka dan analisis menggunakan statistik. Jadi jenis penelitian ini adalah merupakan penelitian Kuantitatif.

Analisis regresi linier ganda digunakan bila peneliti bermaksud meramalkan bagaimana keadaan (naik turunnya) variabel dependen (kriterium), bila dua atau lebih variabel independen sebagai predictor 
dimanipulasi (dinaik turunkan perusahaannya. Usaha berjalan nilainya). Jadi analisis regresi linier ganda akan dilakukan bila jumlah variabel independennya minimal dua. (Prof. Dr. Sugiyono, $2013: 275$ )

Adapun rumus analisis regresi linier berganda sebagai berikut :

$$
\mathrm{Y}=\mathrm{a}+\mathrm{b}_{1} \mathrm{X}_{1}+\mathrm{b}_{2} \mathrm{X}_{2}
$$

Dimana :

$\mathrm{Y}=$ dependen variabel (kepuasan konsumen)

$\mathrm{X}_{1}=$ Daya tanggap

$\mathrm{X}_{2}=$ Kehandalan

$\mathrm{a}=$ konstanta

$b=$ koefisien regresi

\section{HASIL DAN PEMBAHASAN}

Awal merintis usaha Bapak Yudis hanya memiliki satu pegawai saja, pemasaran dan negoisasi untuk mendapatkan pelanggan pada saat itu dia kerjakan sendiri. Ada beberapa cacian serta hinaan yang terlontar dari beberapa orang ketika dia memasarkan jasa usahanya. Menurut Pak Yudis cacian tersebut dianggap sebagai motivasi agar usahanya bisa tersu berkembang. Mulai awal tahun 2012 Bapak Yudis merekrut delapan orang pegawai untuk dipekerjakan di dengan lancar berkat kerja keras pemilik dan pegawainya.

Tahun 2014 CV. Keluarga Mandiri Lamongan memiliki cukup banyak pelanggan, ada delapan pelanggan yang bisa dikatakan sebagai pelanggan prioritas pada perusahaan tersebut. Untuk mengembangkan karirnya Pak Yudis mengikuti pelatihan di Kepulauan Riau, dari hasil pelatihan tersebut Pak Yudis mendapat sertifikat keterampilan kerja. Maret 2015 usahanya sempat mengalami penurunan pelanggan, hal itu disebabkan adanya peraturan baru dari PLN. Agar usahanya tetap bisa berjalan ada banyak hal yang dilakukan agar pelanggan bisa bertambah lagi. Pebruari 2016 mulai ada sedikit kenaikan pelanggan, dan sampai sekarang jumlah pelanggan yang pernah menggunakan jasa instalasi listrik di CV. Keluarga Lamongan Lamongan sekitar 5.788 pelanggan.

Dari persamaan regresi linier berganda dapat diinterpretasikan sebagai berikut :

$\mathrm{Y}=3.881+0,251 \mathrm{X}_{1}+0,465 \mathrm{X}_{2}$

Nilai (a) atau nilai konstanta $=3.881$ 
Menunjukkan bahwa variabel bebas sama dengan nol, maka besarnya kepuasan konsumen yaitu sebesar 3,881 .

Nilai $\left(b_{1}\right)=0,251$

Menunjukkan bahwa nilai koefisien daya tanggap $\left(\mathrm{X}_{1}\right)$ sebesar 0,251 . Tanda positif menunjukkan hubungan yang searah antara daya tanggap dengan kepuasan konsumen, yaitu jika daya tanggap tinggi maka kepuasan konsumen juga tinggi.

Nilai $\left(b_{2}\right)=0,465$

Menunjukkan bahwa nilai koefisien kehandalan $\left(\mathrm{X}_{2}\right)$ sebesar 0,465 . Tanda positif menunjukkan hubungan yang searah antara kehandalan dengan kepuasan konsumen, yaitu jika kehandalan tinggi maka kepuasan konsumen juga tinggi.

Berdasarkan nilai koefisien dan masing - masing variabel bebas, yaitu nilai koefisien daya tanggap $\left(\mathrm{X}_{1}\right)$ sebesar 0,251 dan nilai koefisien kehandalan $\left(\mathrm{X}_{2}\right)$ sebesar 0,465 , dapat diketahui bahwa kehandalan mempunyai nilai koefisien paling tinggi. Hal ini menunjukkan bahwa variabel kehandalan merupakan variabel yang mempunyai kontribusi paling dominan terhadap kepuasan konsumen di CV. Keluarga Mandiri Lamongan.

Berdasarkan hasil uji t dan uji F di atas, maka dapat disimpulkan bahwa Ha diterima dan Ho ditolak, yaitu diduga ada pengaruh baik secara parsial maupun simultan antara variabel daya tanggap dan kehandalan terhadap kepuasan konsumen.

\section{PENUTUP}

\section{Kesimpulan}

Berdasarkan hasil penelitian yang disajikan, maka dapat disimpulkan bahwa :

Dari analisis regresi linier berganda diperoleh persamaan reresi $\mathrm{Y}=3.881+0,251+0,465$. Dari dua variabel tersebut yang mempunyai pengaruh paling dominan adalah variabel kehandalan yaitu sebesar 0,465 satu satuan.

Besarnya koefisien korelasi berganda (R) sebesar 0,791 hal ini berarti menunjukkan adanya hubungan yang kuat antara variabel daya tanggap dan kehandalan terhadap kepuasan konsumen $\mathrm{CV}$. Keluarga Mandiri Lamongan. Dari hasil $\mathrm{R}$ Square $\left(\mathrm{R}^{2}\right)$ adalah 0,625 artinya ada variasi dalam variabel 
bebas daya tanggap dan kehandalan mampu menjelaskan variabel terikat kepuasan konsumen sebesar $62,5 \%$. Sementara sisanya yaitu sebesar $37,5 \%$ dipengaruhi oleh variabel lain di luar persamaan yang telah ditentukan.

Berdasarkan uji $\mathrm{F}$ diketahui bahwa $F_{\text {hitung }}$ sebesar 39.208 lebih besar dari $F_{\text {tabel }}$ sebesar 3,20 serta nilai probabilitas signifikansi sebesar 0.000 lebih kecil dar 0,05 (tingkat kepercayaan yang dipilih) serta Ho diterima dan $\mathrm{Ha}$ ditolak, maka kesimpulannya secara keseluruhan variabel daya tanggap dan kehandalan berpengaruh secara simultan terhadap kepuasan konsumen.

Berdasarkan uji t diketahui bahwa $t_{\text {hitung }}$ sebesar 2,435 lebih besar dari $t_{\text {tabel }} 2,011$, nilai probabilitas signifikasi sebesar 0,019 lebih kecil dari 0,025. Sehingga dapat disimpulkan bahwa secara parsial variabel daya tanggap $\left(\mathrm{X}_{1}\right)$ mempunyai pengaruh yang signifikan terhadap kepuasan konsumen (Y)
Berdasarkan uji $\mathrm{t}$ diketahui bahwa thitung sebesar 3,969 lebih besar dari $t_{\text {tabel }} 2,011$, nilai probabilitas signifikasi sebesar 0,000 lebih kecil dari 0,025. Sehingga dapat disimpulkan bahwa secara parsial variabel kehandalan $\left(\mathrm{X}_{2}\right)$ mempunyai pengaruh yang signifikan terhadap kepuasan konsumen (Y).

\section{DAFTAR PUSTAKA}

Alfabeta Sumarni Murti dan John Soeprihanto. 2014.Pengantar Bisnis. Edisi keenam.

Yogyakarta:Liberty

Kotler dan Keller.2009.Manajemen Pemasaran. Jilid I. Edisi ke 13. Jakarta:Erlangg

Sugiyono. 2013. Statistika Untuk Penelitian.Cetakan Ke22. Bandung: CV Alfabeta

Sugiyono, 2008 Metode Penelitian Bisnis.CV Alfabeta:Bandung

Valarie A. Zeitharal dan Marry Jo Bitner. 2008., Service Marketing. The McGraw Hill Companies, Inc 